\title{
Highly Efficient Genetic Transformation of Bacillus subtilis Attached to Sand Grains
}

\author{
By MICHAEL G. LORENZ,* BAREND W. AARDEMA† AND \\ WILFRIED WACKER NAGEL \\ Arbeitsgruppe Genetik, Fachbereich Biologie, Postfach 2503, Universität Oldenburg, \\ $D$-2900, Oldenburg, FRG
}

(Received 7 July 1987; revised 11 September 1987)

\begin{abstract}
Genetic transformation at the solid/liquid interface was studied using Bacillus subtilis $1 \mathrm{G} 20$ $(\operatorname{trp} C 2)$ with a flow-through system of columns filled with chemically pure sea sand. Studies were done at $23{ }^{\circ} \mathrm{C}$. In one type of experiment, competent cultures were incubated with sandadsorbed DNA, and in another, competent cultures were exposed to sand and then incubated with dissolved DNA for transformation. Of the applied cells, around $10 \%$ were retained in columns filled with DNA-loaded sand and around $1 \%$ in columns with pure sand. Reversible attachment of some of the cells to surfaces of sand grains could be demonstrated. The overall transformation frequencies obtained were 25 - to 50-fold higher than in a standard liquid culture procedure. In this standard procedure, transformation was sensitive to DNAase I concentrations above $50 \mathrm{ng} \mathrm{ml}^{-1}$, whereas in sand columns it was resistant to DNAase I concentrations up to $1 \mu \mathrm{g} \mathrm{ml}^{-1}$. Quantification of transformants eluting from columns indicated that sand-attached cells detach at some point after DNA binding or uptake.
\end{abstract}

\section{INTRODUCTION}

The sorption of micro-organisms to interfaces and its consequences for physiology and ecology have been intensively studied (for reviews see Burns, 1980; Stotzky, 1980; Fletcher, 1984; Stotzky, 1986). Most efforts have focussed on microbial behaviour at the solid/liquid interface. It is well documented that the physiological properties, morphological characteristics and macromolecular composition of micro-organisms change when cells attach to surfaces (Kjelleberg et al., 1983; Filip \& Hattori, 1984; Doran \& Bailey, 1986; Fletcher, 1986). Little information is available about the influence of surfaces on gene transfer processes, although gene exchange in sedimentary environments has been reported (for a review see Stotzky \& Babich, 1986), and transformation seems to be a highly efficient mechanism of gene transfer in soil (Graham \& Istock, 1978).

We have shown that DNA adsorbed to sand is more resistant to DNAases than is free DNA (Lorenz et al., 1981; Aardema et al., 1983). The aim of the studies presented here was to examine whether genetic transformation can proceed at the solid/liquid interface. A preliminary report of some of the results was presented at the XIV International Congress of Microbiology, Manchester, UK, in September 1986.

\section{METHODS}

Sand. Analytical-grade sea sand (Merck) was used throughout. The sand did not contain measurable quantities of clay minerals as determined by X-ray diffraction analysis (Lorenz, 1986). Its composition is described by Lorenz (1986).

† Present address: Wilkemaheerd 32, Groningen, The Netherlands.

Abbreviation: CFCC, cell-free filtrate of a competent culture.

0001-4287 (C) 1988 SGM 
Transforming DNA. DNA was extracted from Bacillus subtilis 168 (Marburg strain, prototrophic, DSM no. 401) according to the method of Marmur (1961) and stored at $4{ }^{\circ} \mathrm{C}$ at a concentration of $575 \mu \mathrm{g} \mathrm{ml}^{-1}$.

Competence. B. subtilis 1G20 (trpC2) was made competent as described by Bron \& Venema (1972). Competent cultures ( 1 litre) were concentrated to approximately $1 \times 10^{10}$ cells ml-1 by centrifugation $(10 \mathrm{~min}$ at $10000 \mathrm{~g})$ and resuspension of the pellet in $20 \mathrm{ml}$ of the supernatant. The stock culture was stored at $-85^{\circ} \mathrm{C}$ in portions of $1 \mathrm{ml}$ with $10 \%(w / v)$ glycerol present. For the experiments, concentrated stock cultures were thawed and diluted to approximately $2 \times 10^{8}$ viable cells $\mathrm{ml}^{-1}$ with the cell-free filtrate of a competent culture (CFCC), prepared by filtration of the supernatant of a competent culture using $0 \cdot 2 \mu \mathrm{m}$ cellulose acetate filters (Sartorius). CFCC was stored in portions of $100 \mathrm{ml}$ at $4{ }^{\circ} \mathrm{C}$.

Loading of sand columns with DNA. All components of the column system and buffers were sterilized before use. Glass columns $(5 \times 70 \mathrm{~mm})$ filled with $0.7 \mathrm{~g}$ sand were autoclaved at $120^{\circ} \mathrm{C}$ for $20 \mathrm{~min}$. The sand was incubated with DNA $\left(0.2 \mathrm{ml} ; 79 \mu \mathrm{g} \mathrm{ml}{ }^{-1}\right.$ in $\left.0.1 \mathrm{M}-\mathrm{NaCl}, 5 \mathrm{~mm}-\mathrm{MgCl}_{2}, 10 \mathrm{~mm}-\mathrm{Tris} / \mathrm{HCl}, \mathrm{pH} 7.0\right)$ for $2 \mathrm{~h}$ at $23{ }^{\circ} \mathrm{C}$. Nonadsorbed DNA was then removed by elution with $5 \mathrm{ml}$ of a solution containing $0 \cdot 1 \mathrm{M}-\mathrm{NaCl}, 5 \mathrm{mM}-\mathrm{MgCl}_{2}, 10 \mathrm{mM}-$ Tris $/ \mathrm{HCl}(\mathrm{pH} 7 \cdot 0)$, and adsorbed DNA was acid-extracted and determined as described by Lorenz et al. (1981). The amount of DNA adsorbed to $0.7 \mathrm{~g}$ sand and the interstitial volume of the sand in the columns were taken as the basis for calculation of the corresponding DNA concentration to be used in experiments other than those with sand-adsorbed DNA. The interstitial volume of the sand bed was determined gravimetrically.

Release of DNA from sand during elution with CFCC was determined. A column filled with DNA-loaded sand was eluted with $6 \mathrm{ml} \mathrm{CFCC}$. The effluent was collected in fractions of $1 \mathrm{ml}$. After elution, the sand was transferred to a $30 \mathrm{ml}$ serum bottle containing $1 \mathrm{ml}$ of a competent culture $\left(1 \times 10^{8}\right.$ cells ml $\left.{ }^{-1}\right)$. Samples $(0.5 \mathrm{ml})$ of the effluent fractions were added to bottles containing $0.5 \mathrm{ml}$ of a competent culture $\left(2 \times 10^{8}\right.$ cells $\left.\mathrm{ml}^{-1}\right)$. The bottles were gently shaken in a water bath at $34{ }^{\circ} \mathrm{C}$ for $30 \mathrm{~min}$, then DNAase I (100 $\mu \mathrm{g} \mathrm{ml}^{-1}$ final concentration) was added. Viable counts and transformants were determined as described below.

Loading of sand with cells and transformation. All experiments were done at $23^{\circ} \mathrm{C}$. A $0.2 \mathrm{ml}$ sample of a competent culture $\left(4 \times 10^{7}\right.$ viable cells per $\left.0.2 \mathrm{ml}\right)$ was layered on top of the sand bed previously loaded with DNA. The sample was quickly passed through the column so that the meniscus came in contact with the top of the sand bed within 1-2 s. This was achieved by pressing in the suspension by means of a silicone suction nozzle put on top of the column. After $2 \mathrm{~min}$ the column was eluted with CFCC at a flow rate of $0.2 \mathrm{ml} \mathrm{min} \mathrm{m}^{-1}$ for 30 min, corresponding to a total volume of $6 \mathrm{ml}$. Before entering the column CFCC was vigorously aerated (a cotton-wool filter was included downstream of the air pump). After elution the sand was removed from the column and transferred to a tube containing $0.8 \mathrm{ml}$ minimal medium (Spizizen, 1958) plus $100 \mu \mathrm{g}$ DNAase I (Boehringer, grade II) $\mathrm{ml}^{-1}$ so that the sand was totally covered with liquid. Then the tube was vortexed for $10-15 \mathrm{~s}$ and incubated for $5 \mathrm{~min}$ at $23^{\circ} \mathrm{C}$ in order to stop further uptake of DNA by cells. (Tests showed that uptake of DNA in sand columns was terminated at DNAase I concentrations higher than $5 \mu \mathrm{g} \mathrm{ml}^{-1}$.) In the effluent of the columns, uptake of DNA was stopped after $30 \mathrm{~min}$ by adding $4 \mu \mathrm{l}$ of a DNAase I solution $\left(10 \mathrm{mg} \mathrm{ml}-1\right.$ in $\left.0.5 \mathrm{M}-\mathrm{MgCl}_{2}\right)$ to $400 \mu \mathrm{l}$ samples of the effluent.

In experiments without adsorbed DNA, a column filled with pure sand was treated exactly as described for columns filled with sand-adsorbed DNA, except that after elution with $6 \mathrm{ml}$ aerated CFCC, $0 \cdot 2 \mathrm{ml}$ of a DNA solution $\left(13.3 \mu \mathrm{g} \mathrm{ml}^{-1}\right.$ in CFCC) was added to the column. The sand was removed from the column, transferred to a tube containing $0.8 \mathrm{ml} \mathrm{CFCC}$ and incubated for $30 \mathrm{~min}$ to allow cells to take up DNA. Further uptake of DNA was then stopped by adding $10 \mu \mathrm{l}$ of a concentrated DNAase I solution $\left(10 \mathrm{mg} \mathrm{ml}^{-1}\right.$ in $\left.0.5 \mathrm{M}-\mathrm{MgCl}_{2}\right)$ and vortexing for $10-15 \mathrm{~s}$. A concentrated DNA solution $\left(40 \mu \mathrm{l}\right.$ of $\left.133 \mu \mathrm{g} \mathrm{DNA} \mathrm{ml}{ }^{-1}\right)$ was added to a tube containing $0.36 \mathrm{ml}$ of the effluent. The tube was gently swirled and incubated for $30 \mathrm{~min}$ to allow cells to take up DNA, then further uptake of DNA was stopped by adding $4 \mu \mathrm{l}$ of a DNAase I solution $\left(10 \mathrm{mg} \mathrm{ml}^{-1}\right.$ in $\left.0.5 \mathrm{M}-\mathrm{MgCl}_{2}\right)$.

The standard transformation procedure was as follows. DNA solution $\left(40 \mu \mathrm{lof} 133 \mu \mathrm{g} \mathrm{ml}^{-1}\right)$ was added to a tube containing $0.36 \mathrm{ml}$ of a competent culture $\left(2 \times 10^{8}\right.$ viable cells $\left.\mathrm{ml}^{-1}\right)$. The tube was gently swirled and incubated for $30 \mathrm{~min}$, then further uptake of DNA was stopped by adding $4 \mu \mathrm{l}$ of a DNAase I solution $\left(10 \mathrm{mg} \mathrm{ml}^{-1}\right.$ in $0.5 \mathrm{M}^{-}$ $\mathrm{MgCl}_{2}$ ).

Attachment studies. Experiments were done essentially as described for transformation studies using pure sand. Two columns filled with pure sand were loaded with cells, eluted with CFCC for $30 \mathrm{~min}$, and the liquid above the sand bed was then removed. To one column $0.2 \mathrm{ml} \mathrm{CFCC}$ and to the other $0.2 \mathrm{ml}$ sterile $\mathrm{H}_{2} \mathrm{O}$ was added, on top of the sand bed. The columns were eluted with $1 \mathrm{ml} \mathrm{CFCC}$ and $1 \mathrm{ml} \mathrm{H}_{2} \mathrm{O}$ respectively, and the effluents were collected. The sand was removed from the columns, transferred to tubes containing $0.8 \mathrm{ml}$ minimal medium and treated for viable cell determination as described below. Viable cells were also determined in the effluents.

Determination of viable cells and transformation frequencies. Viable cells and transformants in supernatants of vortexed sand, in the effluents in elution experiments, and in liquid culture in standard transformation experiments, were quantified as described by Aardema et al. (1983).

Scanning electron microscopy. To a column with pure sand loaded with cells as described, $0.4 \mathrm{ml} 4 \%(\mathrm{v} / \mathrm{v})$ glutaraldehyde in $0.1 \mathrm{M}-\mathrm{NaCl}, 5 \mathrm{~mm}-\mathrm{MgCl}_{2}, 10 \mathrm{~mm}-\mathrm{Tris} / \mathrm{HCl}, \mathrm{pH} 7 \cdot 0$, was added. Fixation was for $18 \mathrm{~h}$. 
Table 1. Transformation of $B$. subtilis in sand and standard liquid culture experiments at $23^{\circ} \mathrm{C}$

Sand-filled columns with DNA (expt A) or without DNA (expt B) were incubated with a competent culture before being eluted with CFCC. Further uptake of DNA was prevented by adding DNAase I to the sand and effluent. Results are the mean \pm standard deviation of five to seven independent experiments. NA, Not applicable.

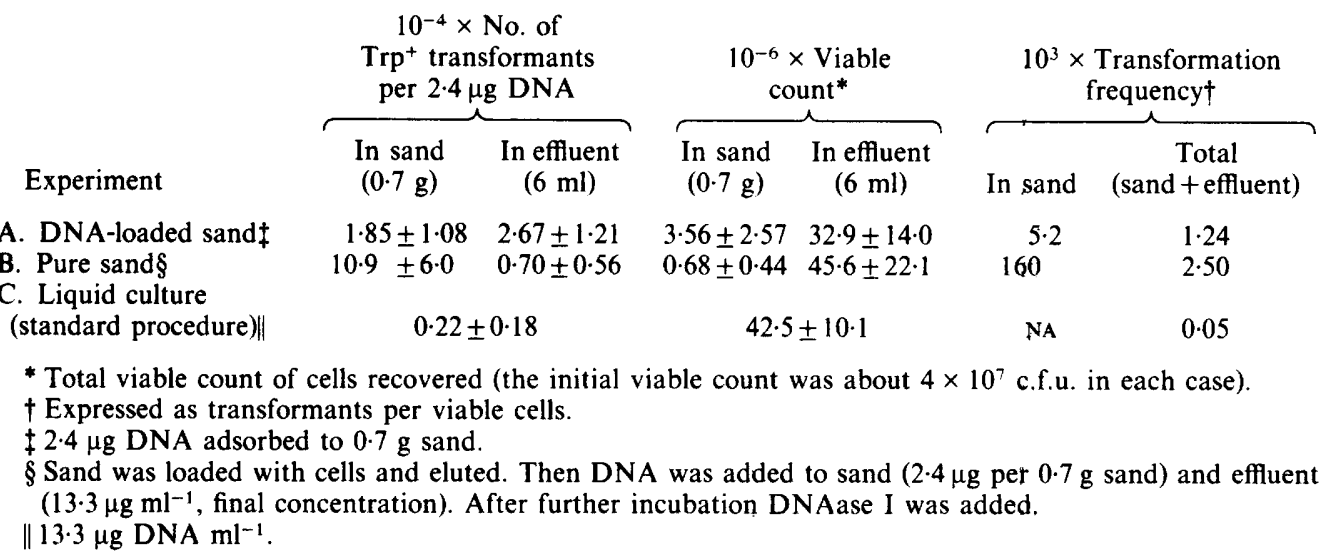

Dehydration was achieved by adding $0.4 \mathrm{ml}$ of an ethanol solution $(10,25,50,75,90$ and $100 \%, 30 \mathrm{~min}$ for each step) to the column. A sample of the sand was mounted on a stub coated with adhesive tape and critical-point dried using liquid $\mathrm{CO}_{2}$ in a Balzers critical-point dryer. The stub was coated with carbon and gold sputtered in a Balzers diode sputter coater. A Cambridge Stereoscan 180 scanning electron microscope was used for examination of the sample.

\section{RESULTS}

Columns filled with sand were loaded with a competent culture of $B$. subtilis $1 \mathrm{G} 20(\operatorname{trpC} 2)$ and eluted for $30 \mathrm{~min}$ with aerated $\mathrm{CFCC}$ at $23^{\circ} \mathrm{C}$. In one type of experiment (Table $\left.1, \mathrm{~A}\right)$ the competent culture was added to DNA-loaded sand $(2.4 \mu \mathrm{g}$ DNA adsorbed per $0.7 \mathrm{~g}$ of sand in a column), in the other (Table 1, B) to sand without DNA (termed pure sand). In experiment A, cells in the effluent and cells which remained in the column after elution were analysed for viable counts and transformants. In experiment B, cells remaining in the column after elution and cells in the effluent were incubated for transformation with a concentration of DNA corresponding to the amount present in the sand in experiment A $(2.4 \mu \mathrm{g}$ DNA per $0.18 \mathrm{ml}$ interstitial volume of the sand bed, which is $13.3 \mu \mathrm{g}^{\mathrm{DNA} \mathrm{m}} \mathrm{m}^{-1}$ ). Transformation was under DNA-saturating conditions (above $1 \mu \mathrm{g} \mathrm{DNA} \mathrm{ml}{ }^{-1}$; data not shown). Standard transformation procedures in liquid culture (Table $1, \mathrm{C}$ ) were done at $13 \cdot 3 \mu \mathrm{g} \mathrm{DNA} \mathrm{ml}^{-1}$. The results show that the total transformation frequencies (Table 1, column 7) in sand columns were 25-fold (DNA-loaded sand, expt A) and 50-fold (pure sand, expt B) higher than in standard transformation experiments (expt $\mathrm{C}$ ). Transformation in the standard transformation procedure was poor at $23{ }^{\circ} \mathrm{C}$, i.e. only $4 \%$ of the transformation frequency at $34{ }^{\circ} \mathrm{C}$.

In experiments with DNA-loaded sand, less than one-fifth of the number of transformants, but approximately five times more viable cells, were detected in the columns than during experiments with pure sand (Table 1). In both cases transformants accumulated in sand, as can be concluded from the high transformation frequencies (Table 1, column 6).

The influence on transformation of various concentrations of DNAase I present during elution of DNA-loaded sand columns was studied (Fig. 1). Transformation in DNA-loaded sand and in effluents was not affected by DNAase I at concentrations up to $1 \mu \mathrm{g} \mathrm{ml}^{-1}$. Even at $5 \mu \mathrm{g}$ DNAase $\mathrm{I} \mathrm{ml}^{-1}$ transformants were found. Transformation in liquid culture, however, was strongly inhibited by DNAase I at concentrations above $50 \mathrm{ng} \mathrm{ml}^{-1}$. 


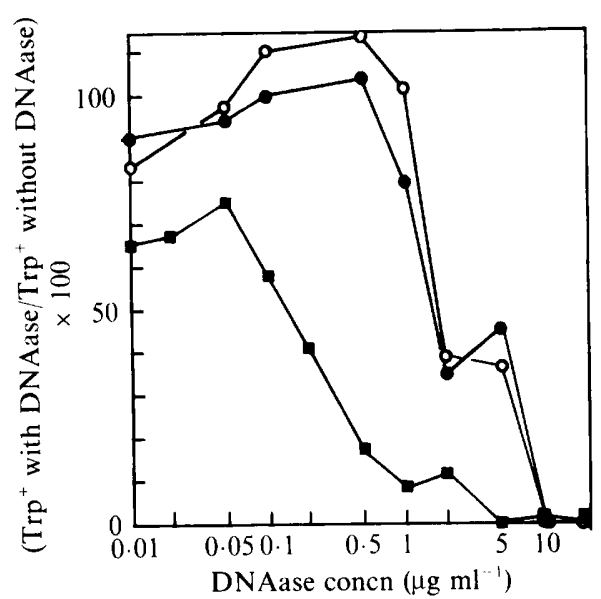

Fig. 1

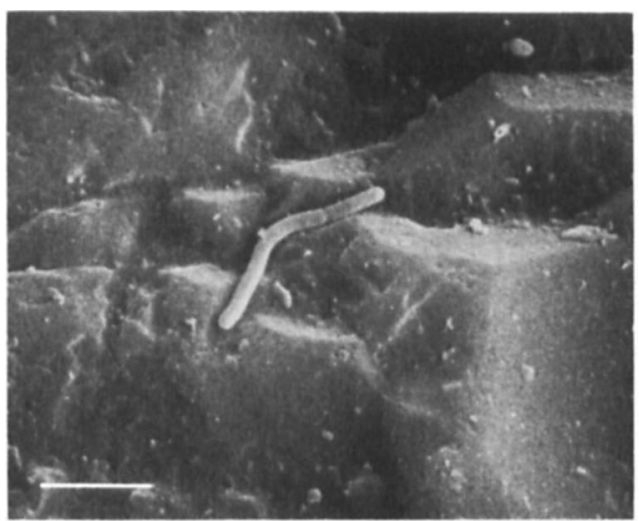

Fig. 2

Fig. 1. Influence of DNAase I concentration in the medium on transformation. Columns filled with DNA-loaded sand (2.4 $\mu \mathrm{g}$ DNA adsorbed to $0.7 \mathrm{~g}$ sand) were incubated with a competent culture and eluted with CFCC plus DNAase I. In the standard transformation procedure DNA was added to a competent culture $\left(13.3 \mu \mathrm{g}\right.$ DNA ml $\mathrm{m}^{-1}$, final concentration) before DNAase I was added. Transformants in sand; $O$, transformants in the effluent; $\square$, transformants determined in standard experiments $(0.4 \mathrm{ml}$ samples $)$.

Fig. 2. Scanning electron micrograph of sand loaded with competent B. subtilis. Bar, $5 \mu \mathrm{m}$.

Earlier experiments had shown a strong association of DNA with sand under defined ionic conditions (Aardema et al., 1983; Lorenz \& Wackernagel, 1987). To see whether DNA desorbed from sand during elution with CFCC, and possibly thereby became available for transformation, the following experiment was done. A column filled with DNA-loaded sand was eluted with CFCC, and the transforming activity was determined in the sand and in the effluent by adding competent cells. Only $3.5 \%$ of the transforming activity was found in the effluent, the rest being in the sand. This low amount of DNA released from sand cannot account for the high frequencies of transformants obtained in experiments with DNA-loaded sand (Table 1: compare expts $\mathrm{A}$ and $\mathrm{C}$ ). To distinguish whether cells attach to sand surfaces or simply remain in the sand by invasion of dents and holes in the grains, a chromatographic approach was used and an electron microscopic examination was made. A competent culture was applied to columns filled with pure sand. After elution with CFCC for 30 min one column was further eluted with $1 \mathrm{ml} \mathrm{CFCC}$ and the other with $1 \mathrm{ml}$ distilled water. Elution with water reduced the amount of cells found associated with sand by $34 \%$ compared to the amount after elution with CFCC. In the effluent of water-eluted columns correspondingly more viable cells $(36 \%)$ were found than in the effluent of CFCC-eluted columns (the viability of cells was not reduced by the reduction of ionic strength). The immediate appearance of cells in the effluent after changing the eluent from CFCC to water shows that a proportion of the cells was attached to sand and that attachment was presumably by means of physical attraction forces (see Discussion). Electron microscopic examination of the sand used showed that it was a heterogeneous mixture of minerals with smooth and rough surfaces. Based on the viable counts associated with sand and the average size of the sand grains, only a few cells per grain were expected. Cells were located only on exposed sites of different minerals, as shown in Fig. 2.

\section{DISCUSSION}

Weak interaction between a proportion of the cells of a competent culture and sand surfaces was demonstrated by elution of cell-loaded sand columns with water. The release of cells by the 
reduction of ionic strength is consistent with the reversible attachment of a bacterial cell to a negatively charged surface at the secondary attraction minimum (see Marshall, 1976). The reason why only $36 \%$ of the cells were released by water is not known. The results obtained so far do not allow one to conclude that cells which were not released by water were attached to sand. However, there was indication that also those cells not immediately eluted by water interacted with sand: electron microscopic examination of cell-loaded sand showed that all cells visible were located on exposed sites of different minerals and not entrapped in holes or dents. It could be that the kind of interaction between sand and those cells which were not released by water is different from reversible attachment. However, these cells could be removed from sand by applying shear force (vortexing). Further studies on this problem are in progress.

Highly efficient transformation of $B$. subtilis in sand at a suboptimal temperature was shown (Table 1). We chose the lowest temperature $\left(23^{\circ} \mathrm{C}\right)$ at which measurable transformation frequencies could be obtained against the background of spontaneous revertants. We think that $23^{\circ} \mathrm{C}$ has more ecological relevance than the optimal temperature of transformation of $B$. subtilis $\left(37^{\circ} \mathrm{C}\right)$. Under DNA-saturating conditions the overall transformation frequencies in our column system (in sand plus effluent) in experiments with sand-adsorbed DNA and with DNA added to cells in sand were 25 - to 50 -fold higher than in the standard transformation procedure at $23{ }^{\circ} \mathrm{C}$ (Table 1). At $37^{\circ} \mathrm{C}$ no difference in transformation frequencies was observed (data not shown). Detailed experiments on this temperature effect are in progress.

At present we can only speculate on the reason for the high transformation efficiency on sand. The fact that in the column system DNA was adsorbed to sand (Table 1, expt A) and that cells were attached to sand (expts A and B) suggests a significant contribution of the solid/liquid interface (sand/medium) to the increased transformation efficiency. This is supported by the observation that transformation by DNA released from sand during elution was negligible. Whether attachment of cells altered their DNA-uptake capability remains to be elucidated. It is known that physiological properties can alter when cells attach to surfaces (Fletcher, 1984, 1986). The transformation frequencies in sand were even higher than the overall transformation frequencies. Apparently transformation was stimulated by the attachment of cells to sand, resulting in up to $16 \%$ transformed cells (Table 1 , expt $\mathrm{B}$ ).

More cells were found in the sand fraction when adsorbed DNA was present than when DNA was absent (Table 1). This means that attachment of cells was positively influenced by the presence of sand-adsorbed DNA. In experiments with DNA-loaded sand the majority of transformants was found in the effluent. This may result from detachment of cells from sand grains during or after the transition of DNA from sand to cells.

Transformation in the standard procedure was strongly inhibited by $1 \mu \mathrm{g}$ DNAase $\mathrm{I} \mathrm{ml}^{-1}$ whereas transformation in sand columns was unaffected (Fig. 1). Transformation in sand proceeded at even higher DNAase I concentrations. We have shown that DNAase I is not inactivated by sand (Lorenz et al., 1981). It is possible that transformation in sand still occurs at high DNAase I concentrations because of a tight contact between attached cells and sandadsorbed DNA, thereby preventing the enzyme from hydrolysing the DNA before it passes over to cells.

It is shown in this paper that in sand the genetic transformation of B. subtilis proceeds with high efficiency at a suboptimal temperature and in the presence of high DNAase I concentrations. Graham \& Istock (1978) reported a high efficiency of transformation of $B$. subtilis in soil even when DNAase was present. The relative stability of DNA in dead cells (Novitzky, 1986) and at surfaces of minerals (Greaves \& Wilson, 1970; Lorenz et al., 1981; Aardema et al., 1983; Lorenz, 1986) has been shown. DNAase-resistant DNA transfer from outgrowing spores to competent cells of B. subtilis (Orrego et al., 1978) and the ability of germinated spores of $B$. subtilis to act as recipients of transforming DNA (Spizizen, 1958) have also been demonstrated. All these data indicate that gene transfer by transformation is likely in natural environments. Our results support the idea that transformation in soil and other sedimentary habitats takes place preferentially at the solid/liquid interface.

We are grateful to Mrs Elke Stead for valuable contributions to the English version of the manuscript. 


\section{REFERENCES}

Aardema, B. W., LorenZ, M. G. \& Krumbein, W. E. (1983). Protection of sediment-adsorbed transforming DNA against enzymatic inactivation. Applied and Environmental Microbiology 46, 417-420.

BRon, S. \& Venema, G. (1972). Ultraviolet inactivation and excision-repair in Bacillus subtilis. I. Construction and characterization of a transformable eightfold auxotrophic strain and two ultravioletsensitive derivatives. Mutation Research 15, 1-10.

BURNs, R. G. (1980). Microbial adhesion to soil surfaces: consequences for growth and enzyme activities. In Microbial Adhesion to Surfaces, pp. 249262. Edited by R. C. W. Berkeley, J. M. Lynch, J. Melling, P. R. Rutter \& B. Vincent. Chichester: Ellis Horwood.

Doran, P. M. \& Balley, J. E. (1986). Effects of immobilization on growth, fermentation properties, and macromolecular composition of Saccharomyces cerevisiae attached to gelatin. Biotechnology and Bioengineering 28, 73-87.

FILIP, Z. \& HATTORI, T. (1984). Utilization of substrates and transformation of solid substrata. In Microbial Adhesion and Aggregation, pp. 251-282. Edited by K. C. Marshall. Berlin: Springer Verlag.

FLETCHER, M. (1984). Comparative physiology of attached and free-living bacteria. In Microbial Adhesion and Aggregation, pp. 223-232. Edited by K. C. Marshall. Berlin: Springer Verlag.

FleTCHER, M. (1986). Measurement of glucose utilization by Pseudomonas fluorescens that are free-living and that are attached to surfaces. Applied and Environmental Microbiology 52, 672-676.

GraHam, J. B. \& Istock, C. A. (1978). Genetic exchange in Bacillus subtilis in soil. Molecular and General Genetics 166, 287-290.

Greaves, M. P. \& Wilson, M. J. (1970). The degradation of nucleic acids and montmorillonitenucleic-acid complexes by soil microorganisms. Soil Biology and Biochemistry 2, 257-268.

KJelleberg, S., Humphrey, B. A. \& Marshall, K. C. (1983). Initial phases of starvation and activity of bacteria at surfaces. Applied and Environmental Microbiology 46, 978-984.

LORENZ, M. G. (1986). Zum Gentransfer in der Natur: Adsorption und Stabilität von DNA an Sand und
Transformation von Bacillus subtilis. Dissertation, Universität Oldenburg.

LORENZ, M. G. \& WaCKernagel, W. (1987). Adsorption of DNA to sand and variable degradation rates of adsorbed DNA. Applied and Environmental Microbiology (in the Press).

Lorenz, M. G., Aardema. B. W. \& Krumbein, W. E. (1981). Interaction of marine sediment with DNA and DNA availability to nucleases. Marine Biology 64, 225-230.

MARMUR, J. (1961). A procedure for the isolation of deoxyribonucleic acid from microorganisms. Journal of Molecular Biology 3, 208-218.

MARSHALL, K. C. (1976). Interfaces in Microbial Ecology. Cambridge, Mass.: Harvard University Press.

Novitzky, J. A. (1986). Degradation of dead microbial biomass in a marine sediment. Applied and Environmental Microbiology 52, 504-509.

Orrego, C., Arnaud, M. \& Halvorson, H. (1978). Bacillus subtilis 168 genetic transformation mediated by outgrowing spores: necessity for cell contact. Journal of Bacteriology 134, 973-981.

SPIZIZEN, J. (1958). Transformation of biochemically deficient strains of Bacillus subtilis by deoxyribonucleate. Proceedings of the National Academy of Sciences of the United States of America 47, 505512.

StotzKy, G. (1970). Surface interactions between clay minerals and microbes, viruses and soluble organics, and the probable importance of these interactions to the ecology of microbes in soil. In Microbial Adhesion to Surfaces, pp. 231-247. Edited by R. C. W. Berkeley, J. M. Lynch, J. Melling, P. R. Rutter \& B. Vincent. Chichester: Ellis Horwood.

StotzKy, G. (1986). Influence of soil mineral colloids on metabolic processes, growth, adhesion, and ecology of microbes and viruses. In Interactions of Soil Minerals with Natural Organics and Microbes, pp. 305-428. Madison: Soil Science Society of America (specific publication no. 17).

Stotzky, G. \& Babich, H. (1986). Survival of, and genetic transfer by, genetically engineered bacteria in natural environments. Advances in Applied Microbiology 31, 93-138. 